\title{
p-ISSN 2302-0970 \\ e-ISSN 2723-0201 \\ PENGARUH KEPEMIMPINAN TERHADAP PARTISIPASI MASYARAKAT DESA SEREANG KECAMATAN MARITENGNGAE KABUPATEN SIDENRENG RAPPANG
}

\author{
1)Asrul Alwi, 2)Nurjannah Nonci, 3)Erfina \\ Fakultas ilmu sosial dan ilmu poltik Universitas Muhammadiyah Sidenreng Rappang \\ asrulalwi43152099@gmail.com \\ erfina.erul85@gmail.com
}

\begin{abstract}
Abstrak
Penelitian ini bertujuan untuk: 1.mengetahui pengaruh gaya kepemimpinan terhadap partisipasi masyarakat di Desa Sereang Kecamatan Maritengngae Kabupaten Sidenreng Rappang. 2. Untuk mengetahui faktor-faktor yang memengaruhi gaya kepemipinan di Desa Sereang Kecamatan Maritengngae Kabupaten Sidenreng Rappang. Jumlah populasi dalam penelitian ini yaitu 779 , dengan jumlah sampel sebanyak 78 orang. Teknik penarikan sampel yang digunakan yaitu random sampling atau sampel secara acak. Teknik pengumpulan data yang digunakan 1.Observasi 2.studi pustaka 3.angket (kuisoner). Data yang terkumpul kemudian di analisis dengan bantuan aplikasi SPSS 16 for windows. Hasil penelitian menunjukkan bahwa 1. pengaruh gaya kepemimpinan terhadap partisipasi masyarakat di Desa Sereang Kecamatan Maritengngae Kabupaten Sidenreng Rappang berada pada kategori Kurang baik dengan persentase sebesar $31,7 \%$. 2. Faktor-faktor yang memengaruhi gaya kepemipinan di Desa Sereang Kecamatan Maritengngae Kabupaten Sidenreng Rappang adalah : Kekuatan berdasarkan paksaan (17,7\%), Kekuatan penghargaan(26\%), Kekuatan keahlian (19,5\%), Kekuatan resmi $(11,9 \%)$, Kekuatan referensi(14,4\%).
\end{abstract}

Kata Kunci : Kepemimpinan Dan Partisipasi Masyarakat

\begin{abstract}
This study aims to: 1. find out the influence of leadership style on community participation in Sereang Village, Maritengngae District, Sidenreng Rappang Regency. 2. To find out the factors that influence the leadership style in Sereang Village, Maritengngae District, Sidenreng Rappang Regency. The population in this study is 779 , with a sample of 78 people. The sampling technique used is random sampling or random sampling. Data collection techniques used 1. Observations 2. library studies 3. cetets (questionnaire). The collected data is then analyzed with the help of SPSS 16 for Windows applications. The results showed that 1. the influence of leadership style on community participation in Sereang Village Maritengngae District, Sidenreng Rappang District was in the unfavorable category with a percentage of $31.7 \%$. 2. What factors influence the leadership style in Sereang Village, Maritengngae District, Sidenreng Rappang Regency are: Strength based on coercion (17.7\%), Strength of appreciation (26\%), Strength of expertise (19.5\%), Official strength $(11,9 \%)$, Strength of reference $(14.4 \%)$.
\end{abstract}

Keywords: supervision and work discipline 


\section{A. PENDAHULUAN}

Kewargaan di Indonesia adalah masyarakat dengan tingkat identitas beragam dari beragam etnis, suku, budaya, dan agama. Peran serta masyarakat dalam pencapaian perkembangan Negara sudah muncul sejak diberlakukannya UU 1945 dan secara konstitusional telah memiliki acuan yang jelas dan merupakan kewajiban bagi siapapun yang terlibat dalam pengelolaan sumberdaya alam di Indonesia. namun peran serta masyarakat dalam pembangunan di era reformasi ini masih memperlihatkan kecenderungan belum berjalan dengan sempurna. Kondisi peran serta masyarakat sejak awal sampai saat ini belum mendapatkan posisi yang tepat dalam bentuk kewenangan dan kewajiban serta hak sebagai masyarakat dalam ikut menjalankan pembangunan. Partisipasi sebagai tindakan untuk "mengambil bagian" yaitu kegiatan atau pernyataan untuk mengambil bagian bagian dari kegiatan dengan maksud memproleh manfaat, Bornby (Aprilia, 2014) Suatu kegiatan atau program tidak dapat berjalan bila hanya dilakukan oleh satu orang saja, maka dari itu partisipasi dari masyarakat atau orang sangat diperlukan.

Berbagai pendapat juga menyatakan bahwa Partisipasi Masyarakat desa merupakan salah satu ciri dari pembangunan desa dan merupakan unsur utama yang berpengaruh besar bagi berhasilnya pembangunan desa. oleh karena itu banyak kegiatan yang dilaksanakan khususnya oleh pemerintah untuk meningkatkan partisipasi, bahkan keberlangsungannya terus diupayakan dan dijaga dalam pelaksanaan pembangunan di desa dan sangat di butuhkan kerjasama yang baik antara pihak masyarakat dan aparat pemerintah, sehingga dapat mewujudkan cita-cita bangsa dan negara yang tertuang dalam UUD 1945 yakni masyarakat yang adil dan makmur. Pencapaian kesejahteraan masyarakat pada dasarnya dilalui dengan jalan perubahanperubahan kehidupan yang lebih baik dari sebelumnya, perubahan tersebut dilakukan melalui pembangunan, tujuan pembangunan masyarakat ialah perbaikan kondisi ekonomi, sosial, dan kebudayaan masyarakat, Lahirnya Undang-Undang Nomor 22 Tahun 1999 yang dimana telah diganti dengan Undang-Undang No. 32 Tahun 2004 tentang Pemerintah Daerah merupakan langkah baru untuk membenahi penyelenggaraan
p-ISSN 2302-0970

e-ISSN 2723-0201

pemerintah, melalui otonomi dan desentralisasi yang diharapkan mampu melahirkan partisipasi aktif masyarakat dan menumbuhkan kemandirian pemerintah daerah.

Secara sederhana, partisipasi masyarakat adalah peran serta atau keikutsertaan masyarakat untuk mendorong rakyat mau berpartisipasi dalam proses pembangunan itu sendiri masih merupakan masalah yang perlu dicari pemecahannya. Mendorong, bukan mengharuskan partisipasi masyarakat; seperti halnya mendorong masyarakat untuk mau berkorban, juga membutuhkan insentif tersendiri. Tidak cukup dikatakan bahwa karena pembangunan itu untuk masyarakat, maka adalah mutlak bila rakyat mau berpartisipasi dalam pembangunan. Pengalaman pembangunan membuktikan bahwa seringkali pembangunan yang dikatakan untuk kepentingan rakyat ternyata tidak sesuai dengan harapan rakyat. Partisipasi masyarakat menurut (Isbandi rukminto, 2007) adalah keikutsertaan masyarakat dalam proses pengidentifikasian masalah dan potensi yang ada di masyarakat, pemilihan dan pengambilan keputusan tentang alternatif solusi untuk menangani masalah, pelaksanaan upaya mengatasi masalah, dan ketertiban masyarakat dalam proses mengevaluasi perubahan yang terjadi. dari teori (Inu Kencana 2002:132) Partisipasi adalah penentuan sikap dan keterlibatan hasrat setiap individu dalam situasi dan kondisi organisasinya, sehingga pada akhirnya mendorong individu tersebut untuk berperan serta dalam pencapaian tujuan organisasi, serta ambil bagian dalam setiap pertanggung jawaban bersama, kemudian Cohen dan Uphoff yang dikutip oleh (Siti Irene., 2011) membedakan patisipasi menjadi empat jenis. Yaitu 1). Partisipasi dalam pengambilan keputusan, 2). Partisipasi dalam pelaksanaan, 3). Partisipasi dalam pengambilan pemanfaatan, dan 4). Partisipasi dalam evaluasi.

Partisipasi di Desa Sereang, memperlihatkan bahwa tingkat partisipasi masyarakat dalam proses keikutsertaan dan pengidentifikasian masalah yang ada di Desa Sereang, ada kecenderungan dalam keikutsertaan masyarakat, salah satunya dalam proses pelatihan mengenai peningkatan kualitas masyarakat dalam pembangunan di Desa Sereang, masyarakat 
masih kurang ikut serta dalam kegiatan tersebut dan masyarakat seakan-akan acuh tak acuh mengenai kegiatan yang diadakan oleh pemerintah desa sehingga timbulnya permasalahan kurangnya pembangunan desa, ini dibuktikan dengan melihat undangan yang di sebar oleh desa berjumlah 50 dan yang hadir berdasarkan absensi yang diedarkan dan di isi oleh masyarakat dengan berikut.

Berdasarkan uraian masalah di atas maka dapat dikatakan ada kecenderungan tingkat partisipasi masyarakat masih kurang di Desa Sereang mengenai program yang diadakan oleh desa yang disebabkan oleh berbagai faktor salah satunya adalah Kepemimpinan yang belum efektif, yang mempunyai pengaruh dalam pengambilan keputusan, dilihat dari masih ada pembngunan jalan yang tidak baik dan beserta masih ada program desa yang tdk terlaksana. pemimpin akan diakui sebagai seorang pemimpin apabila ia dapat memberi pengaruh terhadap perkembangan masyarakat. Kepemimpinan kepala desa merupakan unsur pemerintahan yang paling dekat dengan masyarakat. Kepemimpinan kepala desa sangat dibutuhkan mensukseskan semua pelaksanaan kegiatan desa. Kepala desa mempunyai tugas penyelengaraan desa yaitu : 1). Urusan pemerintahan, antara lain pengaturan kehidupan masyarakat sesuai dengan kewenangan desa seperti, pembuatan peraturan desa, pembentukan lembaga kemasyarakatan, pembentukan badan usaha milik desa, dan kerja sama antar desa, 2). Urusan pembangunan, antara lain pemberdayaan masyarakat dalam penyediaan sarana dan pra sarana fasilitis umum desa seperti, jalan desa, jembatan desa, irigasi, dan pasar desa, 3). Urusan kemasyarakatan, yang meliputi pemberdayaan masyarakat melalui pembinaan kehidupan sosisal budaya masyarakat, seperti bidang kesehatan, pendidikan serata adat istiadat (Tissantotono, 2011 : 7). Kepemimpinan pemerintah desa sangat berpengaruh dalam peningkatan masyarakat di desa, kemudian untuk melihat masalah yang terjadi calon peneliti menggunakan teori dari Kartini Kartono (2008:34) menyatakan indikator kepemimpinan sebagai berikut: (1) sifat (2) kebiasaan (3) tempramen (4) watak (5) keperibadian Berdasarkan uraian
p-ISSN 2302-0970

e-ISSN 2723-0201

sebelumnya calon peneliti merumuskan dalam rancangan penelitian ini yaitu " Pengaruh Kepemimpinan terhadap Partisipasi Masyarakat di Desa Sereang Kecematan Maritengngae Kabupaten Sidenreng Rappang " kemudian tujuan penelitian ini untuk mengetahui pengaruh gaya kepemimpinan terhadap partisipasi masyarakat di Desa Sereang Kecamatan Maritengngae Kabupaten Sidenreng Rappang. Dan untuk mengetahui faktor-faktor yang memengaruhi gaya kepemipinan di Desa Sereang Kecamatan Maritengngae Kabupaten Sidenreng Rappang.

(Yamin, 2010) menyatakan :
adalah suatu proses kepemimpinan adalah suatu proses
memengaruhi yang dilakukan oleh seseorang dalam mengelola anggota kelompoknya untuk mencapai tujuan organisasi. Kepemimpinan merupakan bentuk strategi atau teori memimpin yang tentunya dilakukan oleh orang yang biasa kita sebut sebagai pemimpin. Pemimpin adalah seseorang dengan wewenang kepemimpinannya mengarahkan bawahannya untuk mengerjakan sebagian dari pekerjaannya dalam mencapai tujuan. Sejalan dengan teori diatas peneliti juga menggunakan teori Menurut (Rivai, 2004) kepemimpinan adalah sebuah hubungan yang saling mempengaruhi di antara pemimpin dan pengikut (bawahan) dengan tujuan perubahan nyata yang dicerminkan tujuan bersamanya. Adapun indikator kepemimpinan yang akan dipergunakan dalam pengukuran variabel ini adalah sebagai berikut:

1. Sifat Kamus besar bahasa indonesa (KBBI) mendefenisikan Sifat berarti ciri khas yang ada pada sesuatu untuk membedakan dari yang lain sesuai dengan namanya, maka teori ini mengemukakan bahwa efektifitas kepemimpinan sangat tergantung pada kehebatan karakter pemimpin.

2. Kebiasaan memegang peranan utama dalam gaya kepemimpinan sebagai penentu pergerakan perilaku seorang pemimpin yang menggambarkan segala tindakan yang dilakukan sebagai pemimpin baik.

3. Tempramen adalah gaya perilaku seorang pemimpin dan cara khasnya dalam memberi tanggapan dalam berinteraksi dengan orang lain. Beberapa pemimpin bertemperamen aktif, sedangkan yang lainnya tenang. 
4. Watak seorang pemimpin yang lebih subjektif dapat menjadi penentu bagi keunggulan seorang pemimpin dalam memengaruhi keyakinan (determination), ketekunan (persistence), daya tahan (endurance), keberanian (courage).

5. Kepribadian Kepribadian seorang pemimpin menentukan keberhasilannya yang ditentukan oleh sifat-sifat/ krakteristik keperibadian yang dimilikinya.

H.A.R. (Tilaar, 2009) mengungkapkan partisipasi adalah sebagai wujud dari keinginan untuk mengembangkan demokrasi melalui proses desentralisasi dimana diupayakan antara lain perlunya perencanaan dari bawah (button-up) dengan mengikutsertakan masyarakat dalam proses perencanaan dan pembangunan masyarakatnya. Adapun indikator partisipasi yang digunakan peneliti adalahmenurut Effendi yang dikutip oleh (Siti Irene., 2011), yaitu :

1. Partisipasi Vertikal terjadi dalam bentuk kondisi tertentu masyarakat terlibat atau mengambil bagian dalam suatu program pihak lain, dalam hubungan dimana masyarakat berada sebagai status bawahan, pengikut, atau klien.

2. Partisipasi Horizontal masyarakat mempunyai prakarsa dimana setiap anggota atau kelompok masyarakat berpartisipasi horizontal satudengan yang lainnya.

French dan Raven dalam (Siswanto, 2011) ada bebeapa yang memengaruhi kepemimpinan adalah sebagai berikut:

1. Kekuatan berdasarkan paksaan (coersive power) Kekuatan paksaan artinya pemimpin memerintah orang-orang yang dipmpinnya didasarkan pada kekuatan dan selalu menggunakan ancaman hukuman jika mereka tidak mengikuti perintah, kekuasaan paksaan merupakan kekuasaan yang didasari karena kemampuan seorang pemimpin untuk memberi hukuman dan melakukan pengendalian.

2. Kekuatan penghargaan (reward power) Kekuatan seorang pemimpin dalam memberikan penghargaan kepada orangorang yang dipimpinnya yang memiliki prestasi dalam menjalankan tugas pekerjaannya.

3. Kekuatan keahlian (expert power) Pemimpin dengan pola pengaruh semacam ini biasanya dapat ditemukan
p-ISSN 2302-0970

e-ISSN 2723-0201

dalam organisasi yang menekankan pada profesionalisme, yakni kekuasaan yang berdasarkan karena kepakaran dan kemampuan seseorang dalam suatu bidang tertentu, sehingga menyebabkan para bawahan patuh karena percaya bahwa pemimpin mempunyai pengalaman, pengetahuan dan kemahiran konseptual dan teknikal.

4. Kekuatan resmi (legitimasi power) Kekuasaan atas wewenang berkenaan dengan posisi pemimpin dalam organisasi yang dipimpinnya, bila seorang pemimpin menduduki jabatan dan memiliki kekuasaan secara legitimasi (legitimate power) adalah bila yang bersangkutan dianggap absah memangku jabatannya dan menjalankan kekuasaannya.

5. Kekuatan referensi (referensi power) Pola pengaruh salah satu ini agaknya merupakan akumulasi dari beberapa pengaruh yang mungkin dimiliki oleh seorang pemimpin, konsep kewibawaan hanya dapat dipahami dalam konteks timbal-balik antara pemimpin dan bawahan, kekuasaan yang timbul karena kharisma, karakteristik individu, keteladanan atau kepribadian yang menarik.

\section{B. METODE PENELITIAN}

Jenis penelitian ini menggunakan tipe penelitian asosiatif deskriftif kuantitaif dengan dua variabel yakni variabel $X$ dan variabel $Y$. Adapun Populasi dalam penelitian ini adalah masyarakat yang ada di Desa Sereang yang dengan 779 kepala keluarga dan menggunakan sampel acak yakni mengambil sebagian dari jumlah populasi sebagai sampel sebanyak 78 orang. Teknik pengumpulan data yang digunakan yakni observasi, kuisioner dan studi kepustakaan serta menggunakan tehnik analisis data dengan bantuan program SPSS for windows, hasil analisis berupa statistik deskriptif, uji kualitas data, analisis deskriptif jenis data interval, dan analisis regresi linear sederhana dan uji hipotesis.

\section{HASIL DAN PEMBAHASAN}

Kepemimpinan pemerintah desa sangat berpengaruh dalam peningkatan masyarakat di desa,

1. Pengaruh kepemimpinan terhadap partisipasi masyrakat 
Hasil dari uji coefficients, pada bagian ini dikemukakan nilai konstanta $(a)=1.226$ dan beta $=0,193$ serta $t_{\text {hitungdan tingkat }}$ signifikansi 0,277 , maka model regresi yang digunakan dalam penelitian ini untuk mengukur pegaruh kepemimpinan terhadap partisipasi masyarakat di desa sereang kecamatan maritengngae kabupaten sidenreng rappang, dapat dianalisa berdasarkan koefisiensi sebagai berikut :

$$
Y=1,226+0,193 X
$$

Fungsi regresi di atas, maka dapat dijelaskan

1) Jika variabel kepemimpinan $(X)$ berubah, maka partisipasi masyarakat $(Y)$ juga akan berubah. Tanda positif menunjukkan perubahan yang searah, apabila kepemimpinan baik maka partisipasi masyarakat akan baik dengan kofisiensi regresi sebesar 0,193 dan sebaliknya, jika kepemimpinan tidak baik maka partisipasi juga akan tidak baik dengan kofisiensi sebesar 0,193.

2) Nilai konstanta sebesar 1,226 menunjukkan bahwa jika semua variabel konstan maka kepemimpinan mash bersifat positif.

3) Nilai beta 0,193 diketahui bahwa variabel tidak berpengaruh dominan terhadap partisipasi masyarakat $(\mathrm{Y})$, berdasarkan nilai beta yang kecil

Hasil dari uji ANOVA pada bagian ini ditampilkan hasil yang diperoleh adalah nilai $\mathrm{F}=35,332$ dengan tingkat probabilitas sig 0.000 , untuk menguji kebenaran hipotesis dalampenelitian ini, dilakukanuji $F$. Untuk mengetahui bahwa ada pengaruh/signifikan dapat diketahui denganmelihat dari level of significant $a=0,05$. Jika nilai signifikansi lebih kecil dari 0,05 maka Ho ditolak dan $\mathrm{Ha}$ diterima, berdasarkan hasil olah data pada tabel ANOVA, maka diketahui $F_{\text {hitung yang }}$ diperoleh sebesar 35,332 dengan tingkat signifikansi $0,00(F>0,05)$ yang berarti variabel kepemimpinan (X)mempunyai pengaruh yang signifikan terhadap partisipasi masyarakat $(Y)$ di desa sereang.

1) Nilai thitung variabel kepemimpinan (X) 5,94 dengan tingkat signifikansi 0,00

2) Hipotesis berdasarkan uji $t$ dirumuskan secara statistik sebagai berikut:

$$
\begin{aligned}
& \mathrm{Ha}: \mathrm{P}_{\mathrm{yx}} \neq 0 \\
& \mathrm{Ho}: \mathrm{P}_{\mathrm{yx}}=0 \\
& \text { Hipotesis bentuk kalimat : }
\end{aligned}
$$

1) Hipotesis $\mathrm{Ha}:$ kepemimpinan berpangaruh signifikansi terhadap partisipasi
p-ISSN 2302-0970

e-ISSN 2723-0201

masyarakat di desa sereang kecamatan maritenggae kabupaten sidenreng rappang

2) Hipotesis Ho : kepemimpinan tidakberpangaruh signifikansi terhadap partisipasi masyarakat di desa sereang kecamatan maritenggae kabupaten sidenreng rappang

a) signifikan terhadap partisipasi masyrakat di desa sereang Kecamatan maritengngae Kabupaten Sidenreng Rappang. Pengambilan keputusan : Jika nilai $t_{\text {hitung }} \geq t_{\text {tabel }}$ maka maka $\mathrm{Ho}$ ditolak dan $\mathrm{Ha}$ diterimah, artinya berpengaruh signifikan.

Jika nilai $t_{\text {hitung }} \leq t_{\text {tabel }}$ maka Ho diterima dan Ha ditolak, artinya tidak berpengaruh signifikan. Tabel coeffiecients diperoleh niai $t_{\text {hitung }}=5,94$. Prosedur mencari statistic tabel krateria :

1) Tingkat signifikan $(a=0,05)$ untuk dua pihak

2) df atau dk (derajat kebebasan ) = jumlah data -2 atau $78-2=76$

3) di dapat $t_{\text {tabel }} 2,00$

keputusan : ternyata nilai $t_{\text {hitung }} \geq t_{\text {tabel }}$ atau 5,94 maka Ho ditolak dan Ha diterimah, artinya kepemimpinan berpangaruh terhadap partisipasi masyarakat di desa sereang kecamatan maritenggae kabupaten sidenreng rappang. Hasil dari uji summary yakni

1) $r$ adalah 0,563

2) $r$ square $0,317 \times 100 \%=31,7 \%$ (pengaruh $X$ terhadap $Y$ )

3) sisanya $100 \%-31,7=68,3 \quad$ (sisanya dipengaruhi oleh faktor yang lain) koefisien diterminasi $\left(r^{2}\right)$ digunakan untuk mengetahui pengaruh $X$ terhadap $Y$ dalam menerangkan variasi variabel dependen. Berasarkan tabel model summary koefisien determinasi ( $r$ ) atau $r$ square 0,317 berarti secara bersama sama 31,7 $\%$ perubahan variabel partisipasi masyarakat $(Y)$ dapat dijelaskan oleh variabel kepemimpinan (X). Atau dengan

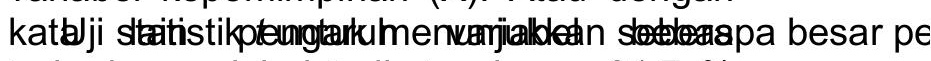
terhadap variabel terikat sebesar 31,7\% sedangkan sisanya yaitu 68,3 dipengaruhi oleh variabel yang tidak masuk dalam kerangka konsep penelitian.

4) Berdasarkan dengan hal yang ada diatas, bahwa pengaruh kepempimpinan terhadap partisipasi masyarakat di desa sereang masih tergolong rendah hal tersebut disebabkan oleh berbagai faktor 
salah satunya adalah Kepemimpinan yang belum efektif, yang mempunyai pengaruh dalam pengambilan keputusan, pemimpin akan diakui sebagai seorang pemimpin apabila ia dapat memberi pengaruh terhadap perkembangan masyarakat. Partisipasi Masyarakat desa merupakan salah satu ciri dari pembangunan desa dan merupakan unsur utama yang berpengaruh besar bagi berhasilnya pembangunan desa. Sebagaimana diatur Lahirnya Undang-Undang Nomor 22 Tahun 1999 yang dimana telah diganti dengan Undang-Undang No. 32 Tahun 2004 tentang Pemerintah Daerah merupakan langkah baru untuk membenahi penyelenggaraan pemerintah, melalui otonomi dan desentralisasi yang diharapkan mampu melahirkan partisipasi aktif masyarakat dan menumbuhkan kemandirian pemerintah daerah.

Faktor- faktor yang memengaruhi kepemimpinan. bahwa nilai $F_{\text {hitungyang }}$ diproleh sebesar 26,675dengan tingkat signfkansi $0,00(F>0,05)$ yang berarti faktor kekuatan berdasarkan penghargaan memiliki pengaruh terhadap kepemimpinan karena tingkat signifikansi tidak melebihi level of ignificant $=0,00$. Nilai $r$ adalah 0,510 dan $r$ square $0,260 \times 100 \%=26 \%$ ( pengaruh faktor ke 2 terhadap kepemimpinan ), berdasarkan tabel model summary kofisien determinasi berganda ( $r 2$ ) atau $r$ square 17,7 \%berarti pengaruh faktor kekuatan berdasarkan penghargaan terhadap kepemimpinan di desa sereang kecematan maritengngae kabupaten sidenreng rappang sebesar $26 \%$.

\section{KESIMPULAN}

Berdasarkan hasil kajian dan penelitian tentang pengaruh kepemimpinan terhadap partisipasi masyarakat di desa sreang kecematan maritengngae kabupaten sidenreang rappang

1. Pengaruh gaya kepemimpinan terhadap partisipasi masyarakat di Desa Sereang Kecamatan Maritengngae Kabupaten Sidenreng Rappang berada pada kategori Kurang baik dengan persentase sebesar $31,7 \%$.

2. Faktor-faktor yang memengaruhi gaya kepemipinan di Desa Sereang Kecamatan Maritengngae Kabupaten Sidenreng Rappang adalah : Kekuatan berdasarkan paksaan (17,7\%), Kekuatan penghargaan
(26\%), Kekuatan keahlian (19,5 \%), Kekuatan resmi (11,9\%), Kekuatan referensi(14,4\%).

\section{E. REFERENSI}

Aprilia, T. (2014). Pembangunan Berbasis Masyarakat. Bandung: Alfabeta.

Isbandi rukminto, A. (2007). Intervensi Komunitas Pengembangan Masyarakat. Jakarta: Raja Grafindo.

Rivai, V. (2004). Manajemen Sumber Daya Manusia untuk Perusahaan. Jakarta: PT. Raja Grafindo Persada.

Siswanto, B. (2011). Manajemen Tenaga kerja Indonesia Pendekatan Administratif dan Operasional. Jakarta: Bumi Aksara.

Siti Irene., A. D. (2011). Desentralisasi dan Partisipasi Masyarakat dalam Pendidikan. Yogyakarta: Pustaka Belajar.

Tilaar, H. (2009). Kekuasaan Pendidikan: Kajian Manajemen Pendidikan Nasional dalam Pusaran Kekuasaan. Jakarta: Rineka Cipta.

Yamin, M. d. (2010). Standarisasi Kinerja Guru. Jakarta: Persada Press. 